\title{
Development of Intercultural Communication Learning Materials Based on Needs Analysis
}

\author{
Tanti Kurnia Sari ${ }^{1}$, Surya Masniari Hutagalung ${ }^{2}$, Indah Aini $^{3}$ \\ ${ }^{1,2,3}$ Universitas Negeri Medan, Indonesia \\ kurniasaritanti@gmail.com,suryamasniari@yahoo.com,aini.indahaini@gmail.com
}

\begin{abstract}
In learning German as Foreign Language (DaF - Deutsch als Fremdsprache), students in The German Language Program at The State University of Medan need to comprehend not only four competencies (Sprechfertigkeit, Lesefertigkeit, Hörfertigkeit, and Schreibfertigkeit), but they also required to have intercultural communication competence. This competence is crucial because there are so many differences between German cultures and Indonesian cultures. This research was conducted at the Faculty of Language and Arts, State University of Medan, in the German Language Education Study Program. The research and development method used in this study refers to Plomp's model, which consists of five steps, namely (1) investigation, (2) design, (3) development realization, (4) evaluation, and (5) implementation. However, in this study, the development process is focused on 3 steps, namely investigation, design, and development realization. Data collection techniques in this needs analysis are questionnaires, literature reviews, and interviews. The data to be analyzed in this study is qualitative data from interviews, observations, and documents. The data were obtained through a questionnaire distributed to 20 alumni of the German Language Study Program who live in Germany. Interkulturelle Kommunikation learning materials were developed based on the results of the questionnaire analysis. The results showed that the learning materials developed included the themes of Familie, Nachbarschaft, Schulsystem in Deutschland, Berufswelt, and Feste, Sinne und Bräuche.
\end{abstract}

Keywords development; learning materials; interkulturelle kommunikation; needs analysis

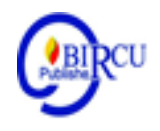

\section{Introduction}

Culture is intellectual happenings like arts, festivals, traditional foods, heritages, or literature but refers to the general population's daily lifestyle or a group of people or individuals. It also describes family life and social life (Maharjan, 2018). Furthermore, Thomas explained that this orientation system was formed from specific signs and became a tradition in that society. This tradition affects the perceptions, thoughts, values, and behavior of all community members. Based on this understanding, it can be understood that culture has significant influences on a person's thoughts and actions.

Culture and language are two things that cannot be separated because language is a mirror of culture and the identity of its speakers. It can be seen by the number of phenomena or realities that indicate a relationship between language and culture. This relationship can take the form of transformation, mutual influence, and so on. According to Koentjaraningrat quoted by Abdul Chaer and Leoni Agustina (1995), language is a part of the culture. The 
relationship between language and culture is a subordinative relationship, where the language is under the scope of culture. However, another opinion states that language and culture have a coordinative relationship, namely an equal relationship, which has the same high position.

One of the functions of language is communication, but this function can sometimes be disrupted if good communication skills do not accompany it. In other words, communication skills support language skills. One of the factors that influence communication skills is culture. Communication carried out by two people of different cultures will fail if they both bring their perspective. Both of them need to understand other cultures and have reciprocal recognition. Therefore having the competence of intercultural communication or Interkulturelle Kommunikation is essential for the students who learn German as Foreign Language. Intercultural communication will not be obtained without having intercultural communication competence, and this competence cannot be gained without intercultural understanding. Intercultural understanding cannot be accepted without intercultural knowledge. Given the importance of intercultural communication competence, it became one of the subjects studied by German learners. The Interkulturelle Kommunikation course is a course that provides students the information about the social and cultural system in Germany, especially about the concepts of culture, family life, neighboring life, the education system, the world of work and profession, and cultural conflicts, as a material for comparison with Indonesian culture. After finishing this course, students have intercultural communication competence to avoid misunderstandings and cultural problems when communicating with Germans.

\section{Review of Literatures}

To achieve this competency, proper learning materials that can support the achievement of learning objectives are needed. Learning materials for the four German language skills can be found online, such as in virtual classes prepared by Deutsche Welle, the Goethe Institut, Klett, and many more. However, the learning materials for the Interkulturelle Kommunikation course are hard to be found. Lecturers must be able to adapt material from various sources and process it into Interkulturelle Kommunikation teaching materials. Learning in the Interkulturelle Kommunikation course provides provisions for associating with Germans for German language students who wish to attend Ausbildung, Au Pair Mädchen, or continue their studies in Germany. Based on this, the development of online learning materials for this course is critical. The learning materials need to be suitable for the real situation and students' needs. To obtain accurate data about students' needs for appropriate learning materials in the Interkulturelle Kommunikation course, a needs analysis was carried out through a questionnaire distributed to German language former students who lived in Germany. The study focused on the survey results about learning materials and strategies. The development process referred to in this case to the Plomp model, which consists of five steps, namely (1) investigation, (2) design, (3) development realization, (4) evaluation, and (5) implementation. However, in this article, the development process focuses on the investigation, design, and implementation phases, namely analyzing the need for suitable learning materials and determining the material based on the needs analysis results and according to the course's competency standards.

Education is one of the efforts to improve the ability of human intelligence, thus he is able to improve the quality of his life. So, to create the highest quality of human resources, education is becoming an important factor to be considered (Sugiharto, 2020). 


\subsection{Learning Materials}

Learning materials are attached to the curriculum's content and must be acquired by students following essential competencies to achieve competency standards in a course. Learning material is the most critical part of the learning process and is the core of learning activities. The learning process's success is determined by students' success in achieving the learning material. The material specified for learning activities should be material that supports the achievement of competency standards and basic competencies and the achievement of indicators.

According to Imelda (2019) The 2013 curriculum hopes are still experiencing many obstacles from both teachers and students. The teacher is still accustomed to using learning by explaining in front of the class, giving examples and giving exercises to be done by students.

In line with Merril's opinion, Taba (1962) also classified learning materials into four levels, namely: 1) Specific facts, 2) main ideas, 3) concepts, and 4) thinking systems. A remarkable fact is the straightforward form of curriculum material. This particular fact is usually the least useful information. Main ideas can be in the form of principles or generalizations of understanding the main ideas, explaining several specific symptoms, or some teaching materials.

\subsection{Development of Online Learning Materials}

The development of online learning in this article refers to the Online Learning Process Guide published by the Directorate of Learning of the Ministry of Research, Technology, and Higher Education 2019. The guide provides directions for learningoriented to the principles of behaviorism, cognitivism, constructivism, and constructivism (2019: 8). It is further explained that the focus of behaviorism is appointed to show that learning is a process of stimulus, response, and feedback, which is applied by paying attention to (1) learning objectives need to be conveyed, (2) learning achievement needs to be assessed, (3) feedback needs to be given. The principle of cognitivism needs to be applied operationally by paying attention to the input-process-output. It means that the material is provided in stages and various ways with various strategies, and there are measurements as evidence of the results of the learning process. It is important to realize that learning news text material is less attractive to students (Nurjanah, 2020).

\subsection{Needs Assessment}

For the learning process to occur optimally so that the learning objectives and competency standards are met, it is necessary to plan a lesson that includes proper learning material. It is needed to carry out a needs analysis so that students' learning material is the material they need the most. A needs assessment is the first step in the development of research activities. Seels and Glasgow (1990) explain the definition of needs assessment: "it means a plan for gathering information about discrepancies and using that information to make decisions about priorities".

To conduct a needs analysis, Glasgow (1990) describes needs assessment in the form of activities starting from the information gathering stage to problem formulation. The needs analysis carried out in this study aims to gather information about the need for Interkulturelle Kommunikation learning materials that suit the situation in the field and line with students' needs. 


\subsection{Intercultural Communication}

Edward Hall, an American ethnologist and lecturer, used the term intercultural communication for the first time. According to its definition, intercultural communication is the interpersonal reaction of people belonging to different cultures. Therefore, intercultural communication is an act of understanding by people with different cultures (the process of exchanging thoughts and meanings). It is a form of interpersonal communication between people from different cultures. It is worth noting that it is a symbolic communication process. The "meanings" of certain gestures are only given within certain cultural groups. They have no meaning in themselves (Stiftungsindex, 2019).

\subsection{The Importance of Intercultural Communication}

Intercultural context is essential in learning a second language. If there are no values, ethics, and behavior in communication, chaos and miscommunication could occur. Likewise, the consequences could be fatal if the communicator does not understand the foreign community's culture whose language is learned. No matter how good someone speaks a foreign language, if he/she does not try to understand its culture, it can be a barrier to build an excellent understanding with the native speaker. Given the importance of intercultural communication, intercultural texts and illustrations need to be included in learning German. From these texts and graphics, learners understand German culture.

According to Bechtel (2003: 54), the exciting thing about learning intercultural understanding is because the learning content is learner-oriented. The learners' cultural characteristics and language are included in the learning process. Intercultural learning is a process of understanding cultural's differences. As Nieke and Kaufmann's explanation above, intercultural learning aims to avoid conflict or misunderstanding, then build a tolerance. What must be considered is how intercultural application in the learning process. The concrete practices that must be developed in intercultural learning according to Hänlscher (1994: 23) are as follows: (i) Linking texts, fairy tales, and stories; (ii) Informing the life of different cultures (learner's culture with the culture of the country of destination language): family, work, education, technology, and so on; (iii) Informing meetings and associations with strangers; (iv) Provide living examples with strangers with tolerance and mutual understanding; (v) Make a theme about the behavior or attitude between people who use the destination language and the students of the destination language.

\subsection{Research on Crosscultural Communication}

Research on intercultural communication has been widely carried out. Turistiati and Agus Rusmana carried out research on intercultural competence in 2018 with the title Developing Intercultural Communication Competence (A Phenomenological Study on Alumni of the Ship for Southeast Asian Youth Program). This research was submitted at the 2nd International Symposium on Social Science, Arts, and Humanities (SYSSARM 2019) in Krabi, Thailand. This article is about the importance of intercultural communication competence of the former students of the Ship for Southeast Asian and Japanese Youth Program (SSEAYP) from Indonesia who work in multinational organizations/companies or institutions. A phenomenological study was used in this research, where they were interviewed and asked about their personal experiences to know how their intercultural communication competence was developed. From the discussion, intercultural communication competence can be acquired by having a motivation to 
communicate with people from different cultural backgrounds; having positive selfmeaning and self-concepts; having direct experiences and intensive and exposure to intercultural communication.

In 2020 Yang, Cheung, Li also conducted similar research under Intercultural Communication Competency Practice in the Hotel Industry (in Journal of China Tourism Research 10.1080/19388160.2020.1807432). Their study aims to develop an in-depth understanding of cultural diversity in China's hotels by examining hotel employees' Intercultural Communication Competency (ICC) practices. Exploratory Factor Analysis and Confirmatory Factor Analysis for scale development were used in this study. The result suggests that identifying competency gaps can help hotels improve service quality through enhanced resource allocation.

In 2017 Cranmer conducted similar research under the title Intercultural Communicative Competence - A Further Challenge (Russian Journal of Linguistic 21 (4): 870-884. 10.22363/2312-9182-2017-21-4-870-884). In this article, Cranmer explained differences between those with weaker intercultural competence and those with an adequate level of intercultural competence. This study analyzes these challenges before hypothesizing what underlying skills and practical strategies might help communicators deal with them. It concluded by stressing the importance of better understanding these challenges and incorporating the development of skills for dealing with them into various teaching programs containing an intercultural component.

\section{Research Methods}

This research was conducted at the Faculty of Language and Arts, State University of Medan, in the German Language Education Study Program. This research is development research based on an initial investigation, namely needs analysis. The needs analysis activity is divided into three major steps, namely (1) the planning stage, (2) the implementation stage, (3) the final stage. The three steps of this activity are included in the investigation phase of the Plomp's development model. A needs analysis was carried out by distributing questionnaires in the form of Google Form. The respondents are German language former Students who live in Germany for quite a long time. They come from different fields. Some of them join Ausbildung, work as Au Pair Mädchen, and as students.

The development process carried out in this study refers to Plomp's model, which consists of five steps, namely (1) investigation, (2) design, (3) development realization, (4) evaluation, and (5) implementation. However, in this study, only three steps were used: investigation, design, and development realization because the research objective in this paper was only for material development. The adaptation of Plomp's (1997: 6-15) development model is used to collaborate between the results of needs analysis and the development of online learning materials. After the alumni have filled in the google form, their answers will be analyzed. The survey analysis results are used as the basis for determining the learning material carried out in the design phase.

\section{Results and Discussion}

The first step in developing Interkulturelle Kommunikation learning materials is to conduct a needs analysis through a questionnaire in the form of a Google Form distributed to former German language students who have lived in Germany. Alumni's answers on the Google Form are then analyzed and mapped according to the competency standards and 
the Interkulturelle Kommunikation course achievement. From the mapping analysis results, actual and indispensable themes were determined to achieve student cross-cultural competence. The themes developed into learning materials for Interkulturelle Kommunikation are 1) Familie in Deutschland, 2) Nachbarschaft, 3) Schulsystem in Deutschland, 4) Berufswelt in Deutschland, and 5) Feste, Sinne und Bräuche. The following is an explanation for each theme.

\subsection{Results}

\section{a. Familie in Deutschland}

This theme's learning achievement is that students know family life in Germany and compare them with family concepts and values in Indonesia. This theme is essential because many German graduates join the Au Pair Mädchen Program, where they have to live with German families, which have different rules from Indonesian families. By studying the Familie in Deutschland material, students understand the concept of family for Germans. Family life in Germany is an exciting thing to understand.

Indonesians hold the principle of being close to family. The influencing factors are the principles of life and the economy. Meanwhile, in Germany, children who are mature enough to leave the house can go without their parents' restrictions. Since they are over seventeen years old, children in Germany have been trying to earn income to be independent. However, some prefer to stay with their parents because they think everything is available in their parents' house.

In Indonesia, living with parents is common except because they study or work in other cities. Even if some are not at home (not married) but are in the same area, it will become a byword in the community. This difference is most likely influenced by how the parents educate their children from their early childhood. From an early age, children in Germany are accustomed to being independent, while in Indonesia, children will always be guided and accompanied by an adult. Indonesians tend to worry about the safety of their children. Parents will always take a look and accompany the child wherever the child moves. In Germany, parents show more independence in parenting, among others, by allowing children to play alone, of course, being adequately supervised.

Familie in Deutschland material in learning is delivered in videos/films and reading texts Bei Mama ist am schönsten, Hotel Mama, and Die Entscheidung. This material is contained in the book Interkulturelle Kommunikation. Indonesian-German, written by Surya Hutagalung in 2016. The learning material is delivered using virtual synchronous and independent/collaborative virtual asynchronous learning methods. A video is also provided, which tells about the differences in lifestyle between family life in Germany and Indonesia. In the independent asynchronous method, students were asked to watch videos, find a picture of the lives of young people and families in Germany, and compare it with young people and families in Indonesia. In the virtual synchronous learning method, students and lecturers discuss the lesson online.

\section{b. Nachbarschaft}

Neighboring life varies widely. There are always differences in neighbors in big cities and small towns due to differences in life situations between urban and rural areas. The same thing happened in Germany. The difference in neighborliness rules between Indonesia and Germany also creates problems for German language graduates living in Germany. Based on this, the theme Nachbarschaft must be included in the Interkulturelle Kommunikation learning material. After studying the Nachbarschaft material, students 
know neighboring life in Germany and compare neighbors' rules in Germany and Indonesia.

Neighboring life in a small town and a big city in Germany is very different. There are neighbors in big cities who do not know each other because of their individual and busy lives, but there is still a cordial relationship between one or two people in small towns. Neighboring life in big cities in Indonesia is also a bit tenuous compared to neighbors lives in a rural area, although it is not very visible. The difference in neighboring life in Germany and Indonesia is marked by regulations governing neighboring life. The Indonesian people are not aware of any neighboring rules. Unlike the German state that already has neighborly life rules, it will refer to the regulation if a problem arises. German insights into the law will help neighbor life in all states in Germany, but the rules vary from state to state.

The material on Nachbarschaft is presented in the form of a reading text entitled "100 Regeln für Nachbarschaft Regeln in einer Wohnung Mietvertrag". This text is included in the book Interkulturelle Kommunikation. Indonesian-German, written by Surya Hutagalung in 2016. Through this text, students can understand the rules of neighborliness in Germany, where rules like this are not found in Indonesia's neighboring life. These rules differentiate neighboring life in Germany and Indonesia so that many alumni have difficulty adapting to neighboring life in Germany. The learning method used is virtual synchronous and collaborative asynchronous. Learning materials are discussed together through online learning media.

\section{c. Schulsystem in Deutschland}

After studying the theme Schulsystem in Deutschland, students know the education system in Germany and compare it with the education system in Indonesia. This theme is essential because Indonesia and Germany have different education systems. For students who are continuing their studies in Germany, this theme is fundamental, so that they have knowledge about the Education system in Germany and will significantly help them adapt to the learning system and academic atmosphere.

Schulsystem in Deutschland material in learning is conveyed through video and recording media with the theme Schulsystem in Deutschland and Erster Tag zur Schule fur Kinder. This material can be found on the page https:/www.berufstrategie.de/bewerbungkarriere-soft-skills/kommunikationsmodelle-sender-empfaenger-modell.php. After seeing the video and recording media, it is hoped that students will no longer experience difficulties in following lectures in Germany and adapting to campus life in Germany. Schulsystem in Deutschland material is delivered using a virtual synchronous learning method in the form of a discussion on comparing the education system in Germany and Indonesia, and independent asynchronous. The learning media used are online learning media in Germany and Indonesia.

\section{d. Berufs welt in Deutschland}

Germany has rules for writing job application letters that are different from writing job application letters in Indonesia. The rules for writing letters, in general, are also different. The German government and German Language Institutions offer many scholarships for Education in Germany. To get these scholarships, they require an application letter (Bewerbungsbrief). Besides, German language former students who wish to participate in Ausbildung in Germany are also required to make an application letter. That is why the theme Berufswelt in Deutschland is crucial so that students do not experience difficulties when writing a scholarship application letter or an application letter 
for Ausbildung. In this theme, workers' rights and obligations are also studied so that students/alumni do not experience difficulties when they have to enter the world of work.

The material for Berufswelt in Deutschland in learning is conveyed through a text on how to write a cover letter in Germany entitled sich bewerben and the rules of the world of work in Germany in a text entitled Berufswelt in Deutschland. This text is included in the book Interkulturelle Kommunikation. Indonesia-Germany, written by Surya Hutagalung in 2016. The learning method used is virtual synchronous and collaborative asynchronous through online learning media.

\section{e. Feste, Sinne und Bräuche}

To meet the indicators and sub-learning outcomes of these Subjects, material in the form of video and reading text with the title Feste und Gebräuche in Deutschland, Oktoberfest, Weihnachten, Neujahr und Silvester are provided so that students can identify cultural celebrations and festivals in Germany. Apart from this material, a video with the theme "Visiting" or "zu Gast sein" was also presented to students. This theme is an exciting theme to discuss because it is very sensitive to the continuation of friendship. Considering the importance of this theme, Feste, Sinne und Bräuche which is focused on "Visiting", is included in the Interkulturelle Kommunikation learning material. Generally in Germany, visiting means there is an appointment beforehand. If there is a sudden visit, it will be called Überraschungsbesuch, and it can cause a problem. Meanwhile, in Indonesia, sudden visits are more desirable to not be a hassle for those visiting. Video is presented to students so that they can see the picture of visiting Germany and Indonesia. A text on the table rules for banquets is also presented. Learning is delivered using a virtual synchronous learning method in the form of discussions through online learning media.

\subsection{Discussions}

\section{a. Familie in Deutschland}

Familie in Deutschland material, which is one of the materials developed, is determined based on Subject Learning Outcomes (CPMK), Sub of Subject Learning Outcomes (Sub CPMK), and Indicators. To support the achievement of Learning Outcomes in the Interkulturelle Kommunikation Subject, students can communicate and avoid misunderstandings and cultural problems when communicating across cultures. The sub CPMK is determined, namely knowing family life in Germany and comparing it with Indonesia's family values. If students learn about family life in Germany and compare it to Indonesia's family life, misunderstandings and cultural problems can be avoided. Based on the CPMK sub and the indicators, the appropriate material was selected in video/film and reading text. Students like the material in the form of video/film because they can see family life in Germany firsthand so that students can easily understand the material. Besides, the delivery of material through videos and movies does not make students feel bored. The reading text chosen is the actual text with the situation in Germany. The sentences used in the text are also easy to understand.

\section{b. Nachbarschaft}

The next sub CPMK is knowing the neighbor rules in Germany, then comparing it with neighbor life in Indonesia. As an indicator to achieve sub CPMK and CPMK is to know neighbor life in Germany and compare neighboring Germany and Indonesia rules. Based on the sub CPMK and Indicators, appropriate learning material is determined in the form of a reading text entitled "100 Regeln für Nachbarschaft Regeln in einer Wohnung Mietvertrag". This reading text describes the rules of neighborliness in Germany. This text 
was chosen because in neighboring life in Indonesia, there are no written rules. To avoid misunderstanding and cultural problems, students must know and understand these rules. This text is very appropriate to support the achievement of indicators, sub CPMK and CPMK of the Interkulturelle Kommunikation course.

\section{c. Schulsystem in Deutschland}

Knowing the education system in Germany and comparing it with Indonesia's education system is the next sub CPMK in the Interkulturelle Communication course. The education system in Indonesia is very different from the education system in Germany. Not a few German language former students continue their education in Germany, which is why the Education system is one of the learning outcomes. For learning outcomes to be more focused, achievement indicators are determined, namely knowing Germany's education system and comparing it to Indonesia. Thus, misunderstandings and problems related to the education system can be avoided. From these indicators and sub CPMK, suitable learning materials were determined in the form of videos and recording media about school life in Germany and the education system in Germany. Interesting videos can increase student motivation in learning.

\section{d. Berufs welt in Deuts chland}

For students to avoid misunderstandings and cultural problems, as stated in the CPMK, it is crucial to learn about Germany's world of work. Based on this, the sub CPMK that supports the achievement of the CPMK is that students know the world of work and the profession in Germany, especially regarding rights and obligations, then compare it with work and professional life in Indonesia. To make it easier to determine learning materials that fit the theme, learning indicators were derived, namely, students could identify job application letters in Germany, know workers' rights and obligations in Germany, and compare professional life in Germany and Indonesia. The first indicator can be achieved through the text on how to write a cover letter in Germany, entitled sich bewerben. The following indicators were achieved through a text entitled Berufswelt in Deutschland.

\section{e. Feste, Sinne und Bräuche}

Misunderstandings and cultural problems can arise if students do not understand the festivities in Germany. Based on this, knowing the major celebrations and cultural festivals in Germany, then comparing them with Indonesia's celebrations becomes an important sub CPMK for fulfilling Subject Learning Outcomes. To make it easier to determine the appropriate material, the sub CPMK section is divided into two indicators, namely, students can identify essential celebrations in Germany and know important celebration procedures in Germany. Thus, the material suitable for achieving these indicators is the visiting procedure and the rules at the dining table. The material for visiting is conveyed through videos so that students get a clear picture of visiting procedures. Meanwhile, the dining table rules are conveyed in an attractive text.

This research is development research using the Plomp's development model, which consists of five steps, namely (1) investigation, (2) design, (3) development realization, (4) evaluation, and (5) implementation. The adaptation of Plomp's development model (1997: 6-15) is used in order to collaborate between the results of the needs analysis and the development of online learning materials. Needs analysis is carried out to obtain accurate information about learning materials according to field needs. The needs analysis is carried out in the investigation phase, which is the initial phase to identify the problems and 
solutions needed. Without this phase, learning design is challenging to do. Because the learning design to be made must be based on the results of a needs analysis.

The learning design that will be made is designed in the design phase. The results of the needs analysis become a reference in determining learning materials. Previously, the Subject Learning Outcomes were selected first, then it was narrowed into the Subject Learning Outcomes and achievement indicators. Furthermore, the material is collected from various sources, then sorted to find suitable material and supports the course learning outcomes. The learning materials collected and under the learning outcomes are then realized into teaching materials for the Interkulturelle Kommunikation course. The evaluation and implementation phases were not carried out in this study because the purpose of this study was to develop learning materials focused on the phase of investigation, design, and development realization.

\section{Conclusion}

The cultural differences between Indonesia and Germany require that students studying German also learn about their culture. So that students have not only language competence but also intercultural competence. Intercultural competence is crucial so that there are no misunderstandings when communicating caused by cultural differences. Students gain intercultural competence through the Interkulturelle Kommunikation course. To meet the course learning outcomes (CPMK), the learning materials are prepared based on a needs analysis so that learning materials are determined, which are useful for students and graduates. The materials studied in the Interkulturelle Kommunikation course are Familie, Nachbarschaft, Schulsystem in Deutschland, Berufswelt, and Feste, Sinne und Bräuche. Learning materials in the form of text and videos are delivered through online learning media using virtual synchronous and independent/collaborative/virtual synchronous learning methods. Learning activities include discussions, questions and answers, and presentations.

\section{References}

Bánhegyi, Mátyás and Judit Nagy. 2019. Teaching Cultural Differences through Korean Canadians: Teaching Material Development for English as a Foreign Language Classes. Acta Educationis Generalis 9(3): 41-65. 10.2478/atd-2019-0013

Bechtel, Mark., 2003. Interkulturelles Lernen beim Sprachlernen im Tandem. Eine diskursanalytische Untersuchung. Tübingen: Narr Francke Attempo Verlag $\mathrm{GmbH}+\mathrm{co}$. KG.

Bethmann, Christine. 2015. Lernprozesse im interkulturellen Training. Studien zur Erforschung Interkultureller Kommunikation. Technische Universität Chemnitz.

Chaer, Abdul., Agustina, Leonie., 1995. Sosiolinguistik: Perkenalan Awal. Jakarta: PT. Rineka Cipta.

Cranmer, R. 2017. Intercultural Communicative Competence - A Further Challenge. In Russian Journal of Linguistic 21 (4): 870-884. 10.22363/2312-9182-2017-21-4-870884

Downes, Siemens., 2020. https://education-2020. wikispaces.com/connectivism

Hänlscher, Petra., 1994. Interkulturelles Lernen, Projekte und Materialien für die Sekunderstufe I. Frankfurt am Main. 
Heringer, Hans Jürgen. 2017. Interkulturelle Kommunikation. 5.Auflage. Tübingen: Narr Francke Attempto Verlag $\mathrm{GmbH}+\mathrm{Co} \mathrm{KG}$.

Hutagalung, Surya Masniari., Pujiastuti, Suci., 2016. Interkulturalität, Mata Kuliah: Interkulturelle Kommunikation. Prodi Pendidikan Bahasa Jerman. Universitas Negeri Medan.

Hutagalung, Surya Masniari., Pujiastuti, Suci. 2018. Die Bewertung der Interkulturellen Kompetenz. Jurnal Ilmiah Bahasa, Sastra dan Budaya Jerman Volume 03.

Imelda, Anzelina, D. (2019). Students' Activities in Learning with Problem Based Learning Based Module to Enhance Students' HOTS on the Subject of Straight Line Equations. Budapest International Research and Critics in Linguistics and Education (BirLE) Journal Vol 2 (4): 552-559.

Irine, Goshhkheteliani and Surguladze Natalia. 2015. Difficulties of Intercultural Communication: Teaching English Speech Etiqeutte to Georgian Students. Journal of Teaching and Education. Georgia.

Kaufmann, Zehnder., Vanderheiden, Frank., 2007. Fortbildung für Kursleitende Deutsch als Zweitsprache. Ismaning: Hueber Verlag.

Lee, Lina. Employing telecollaborative exchange to extend intercultural learning after study abroad. In Jane Jackson \& Susan Oguro (eds.), Intercultural Interventions in Study Abroad. Routledge Publishing, London, UK, 2017.

Liliweri, Alo., 2001. Gatra-Gatra Komunikasi Antar Budaya. Pustaka Pelajar. Yogyakarta

Maharjan. Palistha. 2018. Interkulturall Communication. https://www.businesstopia.net/communication/intercultural-communication.

Meißner. Reiner. 2018. Flüchtlingskrise und Medien als Themen im landeskundlichen Unterricht. Jurnal Ilmiah Bahasa, Sastra dan Budaya Jerman Volume 03.

Merril., 1997. Criteria for Planning the College and Univercity Learning Resources Center. Univercity of Southem California. California

Morska, Liliya. 2018. Teaching Intercultural Communicative Cempetence: Theoritical Background. Ars Linguodidacticae. 10.17721/2663-0303.2018.2.02

Nieke, W., 1995. Interkulturelle Erziehung und Bildung. Wertorientierung im Altag. Opladen.

Nistor, Roxana. 2020.: Love makes the World Go Round, But So Do Second Language Proficiency and Intercultural Communicative Competence. Redefining Community in Intercultural Context 2020. Cluj-Napoca, Romania. https://www.researchgate.net/publication/341592838_Redefining_Community_in_In tercultural_Context_Love_Makes_The_World_Go_Round_But_So_Do_Second_La nguage_Proficiency_And_Intercultural_Communicative_Competence

Nurjanah, S., Daulay, S., and Ansari, K. (2020). The Development of the Assurance Relevance Interest Assessment Satisfaction (Arias) Collaborative Jigsaw Collaborative Learning Model in Writing News Text Class 8 Junior High School State 06 Medan. Budapest International Research and Critics in Linguistics and Education (BirLE) Journal Vol 3 (1): 583-590.

Plomp, Tjeerd., 1997. Educational and Training Systems Design. Introduction. Entschede: University of Twente, Faculty of Educational Science and Technology Entschede.

Roche, Jörg., 2008. Fremdsprachenerwerb Fremdsprachendidaktik 2.Auflage. Tübingen: Narr Francke Attempo Verlag $\mathrm{GmbH}+\mathrm{Co}$. KG.

Samovar, Larry A., Porter, Richard E., 1994. Interculture Communication: A Reader. Boston, Cengage Learning. USA.

Sanjaya, Wina., 2008. Perencanaan dan Desain Sistem Pembelajaran.: Predana Media Grup. 
Schreiter, Miriam. 2015. 'Essen' als Lernfeld für interkulturelles Lernen in internationalen Workcamps. Studien zur Erforschung Interkultureller Kommunikation. Technische Universität Chemnitz.

Seels, B., \& Glasgow, Z., 1990. Exercises in instructional design. Merrill Publishing Company.

Stiftungsindex. 2019. Interkulturelle Kommunikation-Darum ist sie so wichtig. https://www.stiftungsindex.de/interkulturelle-kommunikation-darum-ist-sie-sowichtig.

Sugiharto (2020) Geographical students' learning outcomes on basic political science by using cooperative learning model with Group Investigation (GI) type in State University of Medan, Indonesia, Journal of Human Behavior in the Social Environment, 30:4, 447-456, DOI: 10.1080/10911359.2019.1696261.

Taba, Hilda., 1962. Curriculum Development. Macmilan Publishing. New York.

Turistiati, Ade Tuti dan Agus Rusmana. 2018. Developing Intercultural Communication Competence (A Phenomenological Study on Alumni of the Ship for Southeast Asian Youth Program). Conference: The 2nd International Symposium on Social Science, Arts, and Humanities (SYSSARM 2019). Krabi

Yang, Huijun and Catherine Cheung, Wenjie Li. 2020. Intercultural Communication Compentency Practice in the Hotel Industry. In Journal of China Tourism Research 10.1080/19388160.2020.1807432 